\title{
Contents: Film Education Journal 3(1)
}

Film education pedagogy in Nigeria: A nation-specific approach to a non-Western university curriculum

Lani Akande

Short film production in educational contexts: Exploring the methodology

of the Olhar pela Lente project in Portugal

Pedro Alves and Ana Sofia Pereira

Triangulating a discussion between film, the viewer and a wider frame of life:

Reflections on a life in film education

Mirjana Borčić

Living in a 'digital world': An ethnographic study of film and adolescent literacy education in rural secondary schools in America Jason D. DeHart

Voice, autonomy and utopian desire in participatory film-making with young refugees

Katja Frimberger and Simon Bishopp

Applying Alain Bergala's 'three-phase' model to the history and development of film education in Slovenia

Petra Slatinšek

This is an Open Access article distributed under the terms of the Creative Commons Attribution Licence (CC-BY) $4.0 \mathrm{https} / / /$ creativecommons.org/licenses/by/4.0/, which permits unrestricted use, distribution and reproduction in any medium, provided the original author and source are credited. https://doi.org/10.14324/FEJ.03.1.00. (ISSN 2515-7086). https://www.uclpress.co.uk/pages/film-education-journal 